\begin{tabular}{c} 
Volume and Issues Obtainable at Center for Sustainability Research and Consultancy \\
Journal of Business and Social Review in Emerging Economies \\
ISSN: 2519-089X (E): 2519-0326 \\
Volume 5: No. 2, December 2019 \\
ᄃSRᄃ \\
Journal homepage: www.publishing.globalcsrc.org/jbsee \\
\hline
\end{tabular}

\title{
Does Financial \& Social Development are Important for Economic Growth? An International Scenario
}

\author{
${ }^{1}$ Abdul Rehman, ${ }^{2}$ Irum Saba, ${ }^{3}$ Rehana Kousar \\ ${ }^{1}$ MPhil Accounting \& Finance, Department of Commerce, Bahauddin Zakariya University Multan, Pakistan: \\ raoabdulrehman51@gmail.com \\ ${ }^{2}$ Assistant Professor/Program Director, Department of Finance, Institute of Business Administration (IBA)- \\ Karachi, Pakistan: isaba@iba.edu.pk \\ ${ }^{3}$ Chairperson, Department of Commerce, Bahauddin Zakariya University Multan, Pakistan: \\ rehanakouser@bzu.edu.pk
}

\begin{tabular}{l}
\multicolumn{1}{c}{ ARTICLE DETAILS } \\
\hline History \\
Revised format: November 2019 \\
Available Online: December 2019 \\
\\
Keywords \\
GDP Per Casita, Domestic \\
Credit, Market Capitalization, \\
Capital Formation
\end{tabular}

JEL Classification:

O11, A11, A19

\section{ABSTRACT}

Financial and Social Development plays pivotal role in the economic growth of nations. Developed countries have strong financial and social infrastructure. This study focuses on the social and financial development in relation to economic growth of developed, developing and frontier economies. Gross Domestic product (GDP) per capita used as dependent variable. Domestic credit, market capitalization, turnover ratio, household consumption, foreign direct investment, capital formation, Co2 Emission and trade openness are used as independent variables. government expenditures on education and current health expenditures are use as social variables. Unemployment and inflation rate also use as control variables. Pooled OLS (ordinary least squares), fixed effects and random effects models are used to check the relationship among variables from 2001-2017. Results show positive and significant relation between Gross Domestic product (GDP) Domestic credit, education expenditures and health expenditures in case of developing countries. Market capitalization, turnover ratio, foreign direct investment, and trade openness have a positive but insignificant relationship. Co2 Emission, inflation and unemployment rate have negative and insignificant relation with GDP per capita. In advanced countries Inflation rate trade openness and FDI have positive and significant relation with GDP per capita. Domestic credit, market capitalization, turnover ratio, household final consumption and Co2 Emission have a negative relation with GDP per capita. Education and health also have a negative and insignificant relation with GDP per capita. In Frontier economies there is a positive and insignificant relation of market capitalization, FDI, Co2 Emission and health expenditures with GDP per capita. capital formation, turnover ratio, household consumption, trade openness has negative and significant relation with per capita. Education expenditures have positive and significant relation with GDP per capita. Co2 have positive but insignificant relation. Inflation and unemployment rate have negative but insignificant relation with GDP per capita.

(C) 2019 The authors, under a Creative Commons AttributionNonCommercial 4.0

Corresponding author's email address: rehanakouser@bzu.edu.pk

Recommended citation: Rehman, A., Saba, I. and Kousar, R., (2019). Does Financial \& Social Development Are 
Important for Economic Growth? An International Scenario. Journal of Business and Social Review in Emerging Economies, 5 (2), 315-322

DOI: $10.26710 /$ jbsee.v5i2.923

\section{Introduction}

The impact of financial and social progress on economic growth has been broadly researched globally. There are different expressions that addressed the economic growth factors. Financial development is important for economic development because it provide effective allocation of resources or funds (Afono and Balance Arana 2018). Sustainable economic progress is of primary interest for every economy, mostly in developing nations. Because of insufficient domestic resources for developmental projects in developing nations the role of sustainable growth become more important for the economy. Developing countries heavily rely on foreign wealth or capital like FDI, interbank loans, and remittances. Dependence on higher external debt results in decline of the growth of the economy, which is also due to government debt Wang et al, (2019).

Halos \& Trigoni (2010) examined the impact of financial growth on economic development of European countries and used variables GDP per capita, domestic credit, inflation rate and the deposit rate. Ridzuan et al, (2014) also used four variables and check the dynamic linkages between economic growth, GDP, household consumption, capital formation and government expenditure in Malaysia. Rashid et al, (2016) also used four variables to check the impact of the stock exchange on economic development. Afonso and Blanco-Arana (2018) investigated the impact of financial development variables on the economic growth of $30 \mathrm{OECD}$ countries. The study period used for research was from 1990-2016, with statistical information on financial development variables, GDP per capita, and several control variables. The limitation of the earlier studies is that more variables should be incorporated in future research. This study includes more variables as suggested by various studies 09 FDV (Financial Development Variables) variables and 2 socioeconomic variables and some control variables. Previous studies did not use the social variable impact along with financial growth variables towards Economic development.

The main purpose of this study is to explore the relationship between financial and social progress on Economic growth, where, economic development is measured through the Gross Domestic Product. Financial factors include domestic credit, market capitalization, trade openness, turnover ratio, household consumption, foreign direct investment and capital formation, whereas, health expenditure and government expenditures on education are the measure of social factors. The overall study also observes the impact of some control variables including inflation rate and unemployment.

Therefore, this study delivers advantageous evidence for the impact of financial and social progress on economic development in developed, developing frontier and second emerging nations from the period of 2011 to 2017. In the research panel data set for 29 developed and developing countries is used, whereas previous studies, mostly addressed different OECD countries, developing countries are researched on a specific country.

\section{Literature Review}

Sokhanvar, (2019) examined the relationship of FDI and economic growth in Europe. The samples of seven European Union countries from the period of 1995 to 2014 were used for research and block exogeneity tests were applied. The results showed negative effect of foreign direct investment in nation's economic development.

K. Nath (2005) examined the relationship between FDI, trade openness and development of the economy. Data of thirteen Transition Economies was used and fixed effect and random effect model were applied to analyze the data. There was no significant impact of foreign direct investment on economic development as per the results.

Rehman et al, (2019) examined the connection among macroeconomic variables and economic development of Pakistan. The research focused on long-run relation among variables and covered the time period from 1976 to 2016. ARDL model and bounds test were used to check long-run relation \& short-run relation among FDI, inflation, trade rate, capital formation and labor force. The results showed that there was a negative and a considerable relation between Unemployment and growth of the economy of Pakistan at a level $1 \%$ and 5\%.

Rehman et al, (2019) examined the relation between macroeconomic variables and the growth of Pakistan's economy. The time period included for this research was1976 to 2016 and ARDL model was used for analysis. A negative and significant effect of FDI was found on the growth of the economy of Pakistan. 
Fashina et al, (2019) examined the connection between human capital, foreign aid and development of the Nigerian economy. VECM and Engle-Granger model were used for the purpose of analysis. Positive effects of foreign direct investment on education and economic growth of Nigeria was found

Atul DAR (2019) investigated the output of trade openness on productivity and economic development. The sample includes 27 OECD countries and covered the time period from 2000 to 2015. RCGAM (random coefficient growth-accounting model) was applied, and result showed that there was a positive influence of trade openness on the economic development.

Junying Ma et al, (2019) investigated the impact of openness of trade and local economic development in China. The data of 30 provinces of China for time period from 2002 to 2008 was used. The result showed that trade openness was influenced by the growth of the economy.

P. PRADHAN et al, (2017) investigated the causal relationship between FDI, trade openness, stock market and growth of the economy. The VEC model and cointegration methods were used to check long-run equilibrium among variables. The samples of the 25 ARF (ASEAN regional forum) were used for and the data set covered 1961 to2012. The result found that there was positive among trade openness and economic development.

Ali (2019) examined how FDI impact the economic development of Pakistan from 1975-2017. The variables used for research include Inflation, GDP and FDI, trade openness and capital formation. The research methods like ARDL model and Augmented Dickey Fuller test were applied. The result found that international trade has negative impact on the economic development of Pakistan.

Kriese et al, (2019) investigated the financial development and economic growth of the 102 countries. The Twostage least squares regressions (2SLS) were used for the estimation. The results showed that there was no significant impact of trade openness on the economic development.

Narayan (2010) examined the relationship between the Co2 emission and the growth of the economy with the sample of 43 developing countries and found a negative relationship between them.

Similarly, Bashir M. (2019) explored the impact of Co2 emission, energy and economic development with the samples of 68 countries and concluded that $\mathrm{CO} 2$ emission decreases in MENA countries when economic growth increase. Acheampong, (2018) inspected the relationship among Co2, energy consumption and economic development and found positive impact of carbon emission on the growth of the economy in 116 countries.

Guru and Yadav (2018) examined the relationship between financial development variables and economic development in major five emerging economies BRICS (Brazil, Russia, India, China and South Africa with the sample from 1993 to 2014. They used stock market indicators and banking sector indicator and showed negative relationship on the economic development.

Ali (2019) examined how FDI impact the growth of the economy and worked on Pakistan with the sample period from 1975-2017. They used Inflation, GDP and FDI, trade openness and capital formation. They used ARDL model and found a negative impact of inflation on Pakistan's economic growth.

Afono and Balanco., (2018) explored the relationship between financial growth and economic development. They especially focused on crisis period. They took samples of 30 OECD countries from the period of 1990 to 2016. They took unbalanced panel data and run regression analysis and random effect technique. They found that there was a negative association among inflation \& GDP per capita.

Salian \& Gopakumar (2011) examined the link among inflation \& economic growth. They found negative relationship among variables. In the long run, their study also exposed the negative relationship between inflation and GDP.

Mbulawa (2015) examined the effects of macroeconomic indicators on the growth of the economy of Botswana and also check causal relationship among macroeconomic factors and economic growth. He used annual data and 
covered the time period from 1975 to 2012 and found positive impact of inflation on the economic development of Botswana.

Agalega and Anwati, (2013) observed the effect of interest \& inflation rates on gross domestic product (GDP) of Ghana and found a positive relation among inflation rate and GDP, that indicates when inflation rise GDP also rises.

Kenny S (2019) examined the causal relationship among unemployment rate and growth of the economy. They took samples from Nigeria and covered the time period from 1981 to 2016 . They found that economic growth was affected by unemployment rate.

Afono and Balanco, (2018) explored the relationship between financial growth and economic development, and they especially focused on crisis period. They took samples of 30 OECD countries from the period of 1990 to 2016. They found negative impact of unemployment on GDP and GDP uses as measure economic growth.

\section{Research Methodology}

This section includes the population of the study, sample size, variables description, data collection, measurement of variables, econometric model, and data analysis models.

\subsection{Measurement of Variables}

\begin{tabular}{|c|c|c|c|c|}
\hline Variables & Acronym & Measurement & Reference & Year \\
\hline \multicolumn{5}{|l|}{ Dependent } \\
\hline Gross domestic product & GDP & Per capita & $\begin{array}{l}\text { Afonso \& Balanco } \\
\text { Arana }\end{array}$ & 2018 \\
\hline \multicolumn{5}{|l|}{$\begin{array}{ll}\text { Financial } & \text { Development } \\
\text { Variables (FDV) } & \\
\end{array}$} \\
\hline $\begin{array}{l}\text { Domestic credit provided by the } \\
\text { financial sector }\end{array}$ & Domestic credit & $\%$ of GDP & $\begin{array}{l}\text { Afonso \& Balanco } \\
\text { Arana }\end{array}$ & 2018 \\
\hline \multirow{2}{*}{$\begin{array}{l}\text { Market Capitalization of listed } \\
\text { domestic companies }\end{array}$} & \multirow{2}{*}{$\begin{array}{l}\text { Market } \\
\text { Capitalization }\end{array}$} & \multirow[t]{2}{*}{$\%$ of GDP } & 1-Rashid et al & 2016,2018 \\
\hline & & & $\begin{array}{l}\text { 2- Afonso \& Balanco } \\
\text { Arana }\end{array}$ & \\
\hline $\begin{array}{l}\text { The stock traded, turnover ratio } \\
\text { of domestic shares }\end{array}$ & Turnover ratio & $\begin{array}{l}\text { Ratio of domestic } \\
\text { shares }\end{array}$ & $\begin{array}{l}\text { Afonso \& Balanco } \\
\text { Arana }\end{array}$ & 2018 \\
\hline Household final consumption & $\begin{array}{l}\text { Household } \\
\text { consumption }\end{array}$ & $\%$ of GDP & Ridzuan et al, & 2014 \\
\hline $\begin{array}{l}\text { Foreign direct investment, net } \\
\text { inflows }\end{array}$ & FDI & Net inflows & $\begin{array}{l}\text { Afonso \& Balanco } \\
\text { Arana }\end{array}$ & 2018 \\
\hline Capital Formation & Capital formation & $\%$ of GDP & Ridzuan et al, & 2014 \\
\hline Co2 Emission & Co2 Emission & $\begin{array}{l}\text { Metric ton per } \\
\text { capita }\end{array}$ & $\begin{array}{l}\text { 1. Fortune Uganda } 2 . \\
\text { Zhaohua Wang et al }\end{array}$ & 2019 \\
\hline Trade Openness & Trade Openness & $\%$ of GDP & Onafowora \& Owoye & 2019 \\
\hline \multicolumn{5}{|l|}{ Socioeconomic Variables } \\
\hline $\begin{array}{l}\text { Current health expenditure (\% } \\
\text { of GDP) }\end{array}$ & Health & $\%$ of GDP & Zhaohua Wang et al & 2019 \\
\hline $\begin{array}{l}\text { Govt. Expenditure on education, } \\
\text { total (\% of Govt. Expenditure) }\end{array}$ & Education & $\begin{array}{l}\% \text { of Govt. } \\
\text { Expenditure }\end{array}$ & $\begin{array}{l}\text { Afonso \& Balanco } \\
\text { Arana }\end{array}$ & 2018 \\
\hline \multicolumn{5}{|l|}{ Control Variables } \\
\hline Inflation rate & Inflation rate & $\%$ & $\begin{array}{l}\text { Afonso \& Balanco } \\
\text { Arana }\end{array}$ & 2018 \\
\hline $\begin{array}{l}\text { Unemployment, total (\%of total } \\
\text { labor force) (national estate }\end{array}$ & $\begin{array}{l}\text { Unemployment } \\
\text { rate }\end{array}$ & $\begin{array}{l}\% \text { of total labor } \\
\text { force }\end{array}$ & $\begin{array}{l}\text { Afonso and Balanco } \\
\text { Arana }\end{array}$ & 2018 \\
\hline
\end{tabular}


The sample selection is based on the availability of data for all variables.

The population of the study is based on a FTSE country classification which is following;

\begin{tabular}{|l|l|}
\hline Developed Countries & 17 \\
\hline Advanced Emerging Countries & 8 \\
\hline Frontier Economies & 5 \\
\hline
\end{tabular}

\subsection{Model Specifications}

This study used two models. First model shows impact of financial development variables on the economic growth, and the second model's focus is to find out impact of socioeconomic variables on economic growth. Proposed models are given below:

yit $=\beta 0++\beta 1 F D V$ it $+\Upsilon \mathrm{Xit}+\mathrm{Ki}+€$ it

$\mathrm{y}$ it $=\beta 0++\beta 1 \mathrm{SOC}$ it $+\Upsilon \mathrm{Xit}+\mathrm{Ki}+€$ it

Where yit is the GDP per capita, yit denotes the initial value of GDP per capita, FDV it refers to financial development variables, Xit other control variables and $\mathrm{Ki}$ is intercept for each country, and $€$ it is the individual level residuals.

WDI (world bank development, database) and IFS (international financial statistics) databases are sued for data collection and to build a panel set for the period from 2001 to 2017.

\section{Results \& Discussion}

Table 2 shows that in developed countries financial development variables, domestic credit has positive coefficient and significant relation with the GDP per capita while the household final consumption, co2 emission unemployment rate, inflation rate, capital formation has negative and significant relationship. Only the trade openness, market capitalization, foreign direct investment and turnover ratio has positive but insignificant relationship with gross domestic product. In advanced emerging countries we run simple regression, DC represents the results that domestic credit has negative and significant impact on GDP. Capital formation and inflation rate has positive and significant with economic growth.

There is positive and significant relationship among economic growth and trade openness. There is negative and significant relationship among market capitalization and GDP. Trade openness and household consumption have insignificant negative relation with GDP per capita. Co2 has negative and significant impact on GPD per capita. Unemployment rate has negative and insignificant relation with GDP per capita.

In Frontier Economies Domestic credit and market capitalization has insignificant and positive relation with GDP per capita. There is a negative and significant relationship of turnover ratio and household final consumption among GDP per capita. FDI has positive and insignificant relation with GDP. Capital formation and trade openness have negative and significant relation with GDP per capita.C02 has positive and insignificant relation with GDP per capita. Inflation is negatively correlated and have insignificant impact on economic growth. Unemployment is negatively correlated and have insignificant impact on economic growth.

About socio-economic variables in developed countries there is positive and significant impact of education expenditures and health expenditures on GDP. In the regression model, random effect model shows that, all variables represent the positive association with gross domestic per capita and significant relationship. The fixed effect results show's that the education and household final consumption, has positive coefficient and significant relation with the GDP. 
Model 1

Financial Development Variables

Model 2

Socio-Economic Variable

\begin{tabular}{|c|c|c|c|c|c|c|c|}
\hline Variables & $\begin{array}{l}\text { Developed } \\
\text { Countries }\end{array}$ & $\begin{array}{l}\text { Advanced Emerging } \\
\text { Countries }\end{array}$ & $\begin{array}{l}\text { Frontier } \\
\text { Economies }\end{array}$ & Variables & $\begin{array}{l}\text { Developed } \\
\text { Countries }\end{array}$ & $\begin{array}{l}\text { Advanced Emerging } \\
\text { Countries }\end{array}$ & $\begin{array}{l}\text { Frontier } \\
\text { Economies }\end{array}$ \\
\hline LNGDP & Fixed Effect & OLS & OLS & LNGDP & Random Effect & Fixed Effect & Random Effect \\
\hline \multirow[t]{2}{*}{$\mathrm{DC}$} & $0.0008733^{* * * *}$ & $-0.001706^{*}$ & 0.00381 & EDU & $0.0365019 * * *$ & $0.009428^{*}$ & $0.0237032 *$ \\
\hline & $(-0.0001273)$ & $(-0.000917)$ & $(-0.003029)$ & & $(-0.0070042)$ & $(-0.0056914)$ & $(-0.0125249)$ \\
\hline \multirow[t]{2}{*}{$\mathrm{MC}$} & 0.0002437 & $-0.002285 * * *$ & 0.000607 & HLT & $0.0298416 * * *$ & $0.0538661^{* * *}$ & 0.0538675 \\
\hline & $(-0.0001689)$ & $(-0.0006484)$ & $(-0.003675)$ & & $(-0.0061428)$ & $(-0.0166012)$ & $(-0.0405187)$ \\
\hline \multirow[t]{2}{*}{ TR } & 0.0000663 & -0.001118 & $-0.01022 *$ & $\mathrm{C}$ & $9.85255 * * *$ & $9.276636 * * *$ & $9.018206^{* * *}$ \\
\hline & $(-0.0001274)$ & $(-0.0007955)$ & $(-0.005875)$ & & $(-0.1269012)$ & $(-0.1186418)$ & $(-0.2876063)$ \\
\hline \multirow[t]{2}{*}{$\mathrm{HFC}$} & $-0.0236609 * * *$ & -0.007461 & $-0.01743 * *$ & R-SQUARED & 0.3171 & 0.852732 & 0.1367 \\
\hline & $(-0.0014373)$ & $(-0.0062616)$ & $(-0.006967)$ & BPLM & 0 & 0 & 0 \\
\hline FDI & 0.0004074 & $0.0331862^{* * *}$ & 0.024246 & HAUSMAN & 0.4823 & 0 & 0.9694 \\
\hline
\end{tabular}

\begin{tabular}{|l|l|l|l|}
\hline FDI & $(-0.0006517)$ & $(-0.0092843)$ & $(-0.015578)$ \\
\hline CF & $-0.0085296^{* * *}$ & 0.0274236 & $-0.02061^{*}$ \\
\hline & $(-0.0016131)$ & $(-0.0675122)$ & $(-0.011044)$ \\
\hline TO & 0.0003837 & $0.0142223^{*}$ & $-0.42281^{* *}$ \\
\hline & $(-0.0003641)$ & $(-0.0082411)$ & $(-0.200667)$ \\
\hline CO2 & $-0.0046682^{* * *}$ & $-0.041682^{* * *}$ & 0.008777 \\
\hline & $(-0.000789)$ & $(-0.0103378)$ & $(-0.015692)$ \\
\hline IR & $-0.0088476^{* * *}$ & $0.0196161^{* * *}$ & -0.00664 \\
\hline & $(-0.0023912)$ & $(-0.0052125)$ & $(-0.004747)$ \\
\hline UR & $-0.0186281^{* * *}$ & -0.01183 & -0.01663 \\
\hline & $(-0.0013531)$ & $(-0.0124244)$ & $(-0.017797)$ \\
\hline C & $12.03687^{* * *}$ & $9.770575^{* * *}$ & $11.43054^{* * *}$ \\
\hline & $(-0.1052077)$ & $(-0.6592929)$ & $(-0.547636)$ \\
\hline & 0.983981 & 0.4518 & 0.3675 \\
\hline BPLM & 0 & 1 & 1 \\
\hline HAUSMAN & 0.0003 & $-\ldots$. & - \\
\hline Standar & b & &
\end{tabular}

Standard error in brackets. ${ }^{\star \star *} \mathrm{p}<0.01,{ }^{\star \star} \mathrm{p}<0.05,{ }^{*} \mathrm{p}<0.1$

In advanced emerging countries government spending on education have positive and statistically significant relation with GDP per capita. When government spend more on education that enhance economic growth. On the other hand, Govt. expenditures on education are also has statistically positive and significant relation with economic growth and also increase in GDP per capita. The results indicate that education and health expenditures enhance the economic growth of developing countries.

In frontier economies Government spending on education have positive but statistically insignificant relation with GDP per capita. When government spend more on education that increase economic growth. On the other hand, Govt. expenditures on education are also has statistically positive but insignificant relation with economic growth and also increase in GDP per capita. The results indicate that education and health expenditures have insignificant impact on the growth of frontier economies.

\section{Conclusion}

Based on research results it is concluded that in developing countries, positive and significant relationship exist between Gross Domestic product (GDP), Domestic credit, education expenditures and health expenditures. Market capitalization, turnover ratio, Foreign direct investment, and trade openness have positive but insignificant relationship. Co2 Emission, inflation and unemployment rate have negative and insignificant relation with GDP per capita. In advanced countries Inflation rate trade openness and FDI have positive and significant relation with GDP per capita. Domestic credit, market capitalization, turnover ratio, household final consumption and Co2 Emission have a negative relation with GDP per capita. Education and health also have a negative and insignificant relation with GDP per capita. In Frontier economies there is a positive and insignificant relation of market capitalization, FDI, Co2 Emission and health expenditures with GDP per capita. Capital formation, turnover ratio, household consumption, trade openness has negative and significant relation with per capita. Education expenditures have positive and significant relation with GDP per capita. Co2 have positive but insignificant relation. Inflation and unemployment rate have negative but insignificant relation with GDP per capita. The limitation of the study includes the scarcity of the data especially second emerging countries. Further studies should include the economic variables like poverty level per capita, gross national income and gross national product in order to expand the research. 


\section{References}

Afonso, A., \& Blanco Arana, C. (2018). Financial development and economic growth: a study for OECD countries in the context of crisis. REM Working Paper, 046-2018.

Nath, H. K. (2009). Trade, foreign direct investment, and growth: Evidence from transition economies. Comparative Economic Studies, 51(1), 20-50.

Bouchoucha, N., \& Ali, W. (2019). The impact of FDI on economic growth in Tunisia: An estimate by the ARDL approach.

Wang, Z., Asghar, M. M., Zaidi, S. A. H., \& Wang, B. (2019). Dynamic linkages among CO 2 emissions, health expenditures, and economic growth: empirical evidence from Pakistan.

Mbulawa, S. (2015). Effect of macroeconomic variables on economic growth in Botswana.

Sokhanvar, A. (2019). Does foreign direct investment accelerate tourism and economic growth within Europe? Tourism Management Perspectives, 29, 86-96.

Fashina, O. A., Asaleye, A. J., Ogunjobi, J. O., \& Lawal, A. I. (2018). Foreign aid, human capital and economic growth nexus: Evidence from Nigeria. Journal of International Studies, 11(2), 104-117.

Ridzuan, A. R., Razak, M. I., Ibrahim, Z., Halim, A., Noor, M., \& Ahmed, E. M. (2014). Household Consumption, Domestic Investment, Government Expenditure and Economic Growth: New Evidence from Malaysia. Journal of Scientific Research \& Reports JSRR, 3(17), 2373-2381.

Rashid, S. J., Ouyang, H., Abeid, A. R., \& Pacific, Y. K. T. The Impact of Stock Exchange on Economic Growth: The Case of Mauritius Using VECM Approach.

Antwi, S., Mills, E. F., \& Zhao, X. (2013). Impact of macroeconomic factors on economic growth in Ghana: A cointegration analysis. International journal of academic research in accounting, finance and management sciences, 3(1), 35-45.

Halkos, G. E., \& Trigoni, M. K. (2010). Financial development and economic growth: evidence from the European Union. Managerial Finance, 36(11), 949-957.

Kenny, S. (2019). A causal relationship between unemployment and economic growth.

Pradhan, R. P., Arvin, M. B., \& Hall, J. H. (2019). The nexus between economic growth, stock market depth, trade openness, and foreign direct investment: The case of ASEAN countries. The Singapore Economic Review, 64(03), 461-493

Guru, B. K., \& Yadav, I. S. (2019). Financial development and economic growth: panel evidence from BRICS. Journal of Economics, Finance and Administrative Science, 24(47), 113-126.

Acheampong, A. O. (2018). Economic growth, CO2 emissions and energy consumption: What causes what and where? Energy Economics, 74, 677-692.

Muhammad, B. (2019). Energy consumption, CO2 emissions and economic growth in developed, emerging and Middle East and North Africa countries. Energy.

Narayan, P. K., \& Narayan, S. (2010). Carbon dioxide emissions and economic growth: Panel data evidence from developing countries. Energy policy, 38(1), 661-666.

Ma, J., Shi, J., Luo, D., \& Che, Y. (2019). Effect of trade openness on regional economic growth in China: revisiting the discussion. Applied Economics Letters, 1-4.

Rehman, N. A., Shamshir, M., Hussain, A., \& Sabir, S. (2019). Relationship between major macroeconomic variables and economic growth: A case of Pakistan during 1976-2016.

Amirkhalkhali, S., \& Dar, A. (2019). Trade Openness, Factor Productivity, And Economic Growth: Recent Evidence From Oecd Countries (2000-2015). Applied Econometrics and International Development, 19(1), 5-14.

Kriese, M., Abor, J. Y., \& Agbloyor, E. (2019). Financial access and economic development: the moderating role of financial consumer protection. International Journal of Managerial Finance.

Salian, V. P. (2011). Gopakumar. K. Inflation and economic growth. 


\section{Appendix}

\section{Descriptive Statistics}

\section{Table 1}

\begin{tabular}{|c|c|c|c|c|c|c|c|c|c|c|c|c|}
\hline \multicolumn{5}{|c|}{ Developed Countries } & \multicolumn{4}{|c|}{ Advanced Emerging Countries } & \multicolumn{4}{|c|}{ Frontier Economies } \\
\hline Variables & MEAN & STD.DEV. & MIN & MAX & MEAN & STD. DEV. & $\mathrm{MIN}$ & MAX & MEAN & STD.DEV. & MIN & MAX \\
\hline LNGDP & 10.57598 & 0.306831 & 9.61 & 11.382 & 9.755117 & 0.308431 & 9.15044 & 10.3758 & 9.587588 & 0.367988 & 8.598 & 10.089 \\
\hline DC & 142.2517 & 43.10619 & 83.699 & 223.604 & 102.7189 & 45.92905 & 27.2521 & 192.66 & 51.56096 & 28.178 & 16.316 & 113.454 \\
\hline $\mathrm{MC}$ & 71.19536 & 40.79759 & 27.904 & 158.801 & 76.00303 & 73.1621 & 10.3579 & 352.292 & 24.36788 & 19.62014 & 5.887 & 72.102 \\
\hline $\mathbb{R}$ & 65.50385 & 36.88915 & 13.621 & 126.589 & 60.90057 & 43.70176 & 17.6776 & 191.193 & 9.906694 & 6.793571 & 1.628 & 26.566 \\
\hline $\mathrm{HFC}$ & 53.62027 & 7.257963 & 31.656 & 66.332 & 59.24699 & 6.922649 & 43.9978 & 70.7723 & 63.60111 & 8.194533 & 42.191 & 74.835 \\
\hline FDI & 5.622886 & 6.663773 & 0.149 & 20.87 & 2.630886 & 1.901402 & 0.022231 & 7.541286 & 3.539365 & 3.290976 & -0.6 & 13.013 \\
\hline $\mathrm{CF}$ & 22.37062 & 3.075467 & 14.754 & 31.823 & 21.79019 & 3.919308 & 11.5186 & 29.8091 & 22.55994 & 4.595054 & 11.961 & 37.287 \\
\hline TO & 88.02331 & 40.80935 & 42.108 & 164.698 & 4.290477 & 0.615896 & 3.09585 & 5.34889 & 0.714118 & 0.284259 & 0.219 & 1.298 \\
\hline $\mathrm{CO} 2$ & 7.177671 & 4.204052 & 0 & 18.2 & 4.435387 & 2.93921 & 0 & 9.8706 & 3.927506 & 3.904776 & 0 & 12.584 \\
\hline $\mathbb{R}$ & 1.620284 & 1.395367 & -0.458 & 3.921 & 5.118951 & 3.158757 & -0.3745 & 12.03734 & 11.52362 & 9.354531 & -1.096 & 41.119 \\
\hline UR & 7.275239 & 4.17915 & 1.69 & 26.09 & 9.386779 & 7.748527 & 0.49 & 27.47 & 7.288788 & 2.630741 & 3.88 & 19.59 \\
\hline $\mathrm{EDU}$ & 12.69295 & 3.07196 & 8.007 & 21.807 & 15.196 & 5.175475 & 5.94852 & 25.9036 & 12.85287 & 3.042742 & 8.271 & 20.905 \\
\hline HLT & 8.716422 & 1.92925 & 2.853 & 12.248 & 6.223078 & 2.248878 & 2.72418 & 11.7715 & 4.914435 & 1.741469 & 2.692 & 9.009 \\
\hline
\end{tabular}

